\title{
Domestic lead arranger certification and the pricing of project finance loans
}

\author{
Frederick S. Ahiabor, Gregory A. James* \\ Department of Accounting and Finance \\ Leicester Castle Business School, De Montfort University \\ Leicester, UK
}

\begin{abstract}
Using a sample of 1,270 project finance syndicated loan tranches arranged from 1998 to 2011 and worth over $\$ 300$ billion, we estimate the causal impact of certification by domestic lead arrangers on the pricing of project finance loans in emerging markets. We hypothesize that, on average, domestic arrangers are better able to structure and screen project finance deals, credibly communicate the true value of a project and its underlying network of contracts, and monitor the loan contract compared to foreign arrangers. If so, all things being equal, domestic arranger certification should result in lower loan spreads compared to foreign arranger certification. Our results support this hypothesis. After controlling for project and loan characteristics and the potential endogeneity of the lead arranger's selection, we find that certification by domestic arrangers causes a significant reduction in loan spreads across different industrial categories and geographic locations of projects. This finding demonstrates the economic value of domestic arranger certification in project finance lending. Our results suggest that, in the presence of information asymmetry between project sponsors and participant lenders in the syndicate, certification by domestic arrangers offers a superior mechanism to minimize search, information and monitoring costs.
\end{abstract}

Keywords: Project finance, loan pricing, certification, mandated lead arranger, financial intermediaries, syndicated lending, asymmetric information, emerging markets JEL: G20, G21, G15

\footnotetext{
*Corresponding author. Department of Accounting and Finance, Leicester Castle Business School, De Montfort University, Leicester, LE1 9BH, UK.

Email address: gregory.james@dmu.ac.uk (Gregory A. James)
} 


\section{Introduction}

Over the past two decades, project finance (PF) has become an increasingly popular vehicle for channelling capital into emerging markets (Gatti et al., 2013). In 2017, the total value of global PF transactions was worth $\$ 229.6$ billion, based on data compiled by Thomson Reuters Deals Intelligence (Thomson-Reuters, 2017). Approximately $\$ 80.6$ billion $(35 \%)$ of these deals were undertaken in emerging markets to finance long-term infrastructure projects in transportation, water and sewage, power, oil and gas and mineral explorations. As Ansar (2012) points out, the surge in the use of PF in emerging markets is partly underpinned by an increasing involvement of homegrown, and often state-backed, financial intermediaries (FIs).

According to Esty (2014), a PF transaction “...involves the creation of a legally independent project company financed with nonrecourse debt (and equity from one or more corporations known as sponsoring firms) for the purpose of financing investment in a single purpose capital asset, usually with a limited life." Financing is secured on the basis of the underlying project's ability to generate enough cash flow for repayment. This absolves the sponsors from any future liability arising from project failure. PF deals are typically structured as syndicated loans, led by one or more mandated lead arrangers (MLAs). The role of the lead arranger in PF is particularly critical since the loan is nonrecourse. The lead arranger is appointed by the sponsors through a competitive tendering process (Della Croce and Gatti, 2014) and principally responsible for undertaking due diligence. The lead arranger also examines the project company's network of contracts and invites participant lenders to provide a share of the PF loan.

The non-involvement of syndicate members in the due diligence process induces asymmetric information at the level of the lead arranger (Focarelli et al., 2008). The lead arranger is an "informed lender" who is able to monitor and learn about the firm through unobservable and costly effort whereas potential participant lenders in the syndicate are "uninformed lenders" who rely on the information and monitoring provided by the informed lender to make profitable investment in firms (Holmstrom and Tirole, 1997). To overcome the problem of moral hazard at the lead arranger level, given that informed lender effort is unobservable, the lead arranger must retain a stake in the borrowing firm to reassure the syndicate members that the firm will behave diligently. When the borrower requires more intense investigation and monitoring, the lead arranger retains a larger portion of the loan to commit to exerting costly effort. Another possible solution to this moral hazard problem is reputation.

Lead arrangers that retain a larger portion of the loan or reputable lead arrangers communicate a meaningful signal (see Brealey et al., 1977) about the project's true value and the lead arranger's commitment to monitoring, especially when dealing with new or information-sensitive borrowers (Drucker and Puri, 2007). Thus, the lead arranger facilitates a reduction in the loan spread through a reduction in search and information costs and the alignment of the lead arranger's incentives with that of other members of the syndicate. Dennis and Mullineaux (2000), Sufi (2007), Chaudhry and Kleimeier (2015), and Lee and Mullineaux (2004) provide empirical evidence that the syndicate structure is less concentrated with arrangers syndicating a greater portion of the loan when the borrowing firm is public, the loan amount is large, and the arranger has a strong reputation. Vu and Skully (2008), Ivashina (2009), and Nini (2004) show that loan spreads are lower when the arranger discloses more information to the syndicate members, holds a higher share of the loan, has a strong reputation, and is local. Kleimeier and Chaudhry (2015) find that foreign arrangers in the US syndicated loan market hold 
high lending shares to overcome moral hazard driven by higher information and effort costs. They show, however, that previous interactions between borrowers and arrangers can reduce moral hazard, hence culturally distant arrangers are able to form diffused syndicates.

A number of studies investigate arranger certification in securities underwriting. ${ }^{1}$ Underwriter syndication is used to credibly commit against opportunistic behavior (the possibility of banks using their lending-generated relationship to benefit themselves and the issuing firm at the expense of investors) and to exploit their inside knowledge to lower issuance costs for borrowing firm issuers (Narayanan et al., 2004). However, explaining certification as an application of the inside knowledge of the certifying agent obtained through prior transactions with the issuer is probably not a valid argument for PF (Gatti et al., 2013). This is because PF involves a newly established project that is operationally separate from the sponsors. In PF, as Gatti et al. (2013, p.2) argue, "the ability to certify arises from the superior ability of the arranging bank to structure and screen the deal set up by the sponsors, as well as to later monitor the loan contract or resolve financial distress situations." Hence, Gatti et al. (2013) examine lead arranger certification specifically in the context of PF lending. Using a sample of 4,122 project finance loans arranged from 1991 to 2005, they find that PF loan spreads are significantly lower for loans arranged by "prestigious" arrangers (banks that have a high market share in the PF loan market in the year or years prior to the signing date of the loan) as compared to loans arranged by nonprestigious lead arrangers. Furthermore, they show that participating banks, rather than PF sponsors, "pay" for the certification provided by prestigious banks by allowing them to keep larger fractions of upfront arranging fees.

This paper builds on the work of Gatti et al. (2013) and empirically examines the causal effect on loan pricing of certification by domestic lead arrangers in emerging markets. $^{2}$ We hypothesize that the domestic certifying agent has informational advantages in accessing so-called "soft information", that is, information which is difficult to completely summarize in a numeric score (Petersen and Rajan, 2002). As Corielli et al. (2010) show, lenders in PF rely on the network of "nonfinancial contracts" (see Alchian and Demsetz, 1972; Jensen and Meckling, 1976) as a mechanism to control agency costs and project risks. ${ }^{3}$ The literature on foreign banking, which focuses primarily on the activities of foreign banks in emerging markets (e.g. Giannetti and Ongena, 2012) and emphasizes the informational disadvantages faced by foreign banks provides arguments and evidence in support of this hypothesis. Foreign banks have less local, market or firm specific information than their domestic counterparts and must also overcome cultural

\footnotetext{
${ }^{1}$ These studies support the proposition that certification reduces loan prices, especially when commercial banks, rather than investment banks, are the certifying agents. This is attributed to the commercial bank's ability to use private information about the issuing firm obtained from a pre-existing lending relationship to reduce search and information costs (Puri, 1996, 1999; Gande et al., 1997). Other studies, however, argue in favor of certification by investment banks due to the potential conflict of interest that may arise when a commercial bank certifies a low quality project in order to use the proceeds of the issue to draw down its existing loans with a lender (Kroszner and Rajan, 1997). Commercial bank certification may also lead to the so-called "lock up" of the borrower. In other words, the commercial bank can successfully prevent the borrower from being able to choose an alternative lead arranger (Kanatas and Qi, 1998; Puri, 1999).

${ }^{2}$ In this study we define a domestic arranger as a FI that is ultimately owned by shareholders domiciled in the same country as the project country and is not a subsidiary of a foreign parent company.

${ }^{3}$ Nonfinancial contracts are contracts that generate cash inflows or outflows that affect the unlevered free cash flows of the project company.
} 
and bureaucratic barriers in the host country (see Khanna and Palepu, 1999; Buch, 2003; Petersen and Rajan, 2002; Mian, 2006). Knyazeva and Knyazeva (2012) find that loan spreads are increasing in the geographical distance between borrowers and lenders due to the difficulty in obtaining and verifying soft information over distances. Degryse and Ongena (2005) and Mian (2006) report similar findings.

In $\mathrm{PF}$, we posit that the disadvantages faced by foreign banks in the project country give domestic arrangers superior ability to assess projects and their underlying network of contracts, credibly communicate the project's true value, and provide effective monitoring of the project company. If this hypothesis is correct, loans can be arranged at lower spreads by domestic arrangers (with or without the participation of foreign arrangers) than by foreign arrangers alone.

We test this conjecture using a sample of 1,270 PF syndicated loan tranches signed across 53 emerging markets between 1998 and 2011 and worth over $\$ 300$ billion. $^{4}$ We merge market data on PF deals from the ProjectWare database by Dealogic with ownership data on the lead arrangers and lenders participating in the loan syndicate obtained from the Bankscope and Zephyr databases (Bureau van Dijk). We use the information on global ultimate ownership contained in the Bankscope database to categorize the FIs in our sample as domestic or foreign with reference to the project country. We use the Zephyr database on merger and acquisitions to identify FIs that experienced a change in ownership over the period under consideration. In order to categorize those FIs that underwent ownership change over the sample period as domestic or foreign we consider the FI's global ultimate owner at the time the PF loan was signed.

This paper contributes to the existing literature on certification in at least three ways. ${ }^{5}$ First, this is, to the best of our knowledge, the first study to investigate the pricing effect of certification by domestic lead arrangers specifically in the context of PF loan syndication. In doing so, the paper builds on the work of Gatti et al. (2013) on the effect of prestige on certification in PF lending. ${ }^{6}$ The paper also builds on the work of Haselmann and Wachtel (2011) on the differential effect of certification by domestic vs. foreign banks in syndicated lending. The latter find that domestic arrangers and foreign arrangers behave differently with foreign banks charging a higher spread (after controlling for borrower and loan characteristics) in large as compared to small financial markets in Europe. ${ }^{7}$

Second, the paper uses a switching regression model with endogenous switching to account for the potential endogeneity of the arranger's selection. The findings of Hasel-

\footnotetext{
${ }^{4}$ See the Methodology section for a discussion of how a country is selected as an emerging market.

${ }^{5}$ The paper also contributes to the wider literature on the role of FIs as delegated monitors à la Diamond (1984) where the lead arranger is charged with monitoring the firm. Our analysis provides new insight into whether, in the context of PF lending, domestic arrangers are better delegated monitors of project companies than foreign arrangers.

${ }^{6} \mathrm{~A}$ domestic arranger can also be a prestigious arranger, for instance if it succeeds in exploiting a home advantage to build profitable market share over the long run. However, only a total of 6 domestic arrangers in our sample can also be categorized as prestigious, according to the league table of the top 25 PF lead arrangers published in Gatti (2013, pp. 175-178). These arrangers are Gulf International Bank (Bahrain) and Chiao Tung Bank (China) for the period 1998-2005, and State Bank of India (India), Axis Bank (India), IDBI Bank (India), and Korea Development Bank (Korea) for the period 2006-2011.

${ }^{7}$ Haselmann and Wachtel (2011) find that in large financial systems foreign banks tend to lend to significantly more leveraged borrowers than domestic banks and take on especially risky projects. Foreign banks diversify these risks by international syndication. In contrast, in small financial markets, foreign arrangers go to larger and often publicly listed firms with more tangible assets.
} 
mann and Wachtel (2011) show that the involvement of a foreign or domestic bank as lead arranger in a loan syndicate may not be random. The domestic FI's superior knowledge of the borrower's country and of local market conditions (Berger et al., 2001; Mian, 2006) suggests domestic arrangers may have a comparative advantage in dealing with project companies that require more due diligence and monitoring. Domestic arrangers can also help mitigate political risks associated with the project. Domestic FIs often have stronger political connections with the government of the borrower's country, making it difficult for the latter to take actions that jeopardise the viability of PF investments, especially when the FI is state-owned (Esty, 2004).

Third, the paper focuses specifically on PF syndicated loans in emerging markets, which account for a significant and rapidly growing share of the global PF market. Carrying out due diligence in emerging markets can be more difficult since, by definition, institutions are nascent and information frameworks less developed. Furthermore, emerging markets are more prone to macroeconomic shocks as well as country and political risks (Dailami and Leipziger, 1998). Hence, this paper provides new insight into an important function of intermediation in developing economies.

We find that certification by domestic arrangers causes a reduction in the loan spread by 24 basis points on average (after controlling for project and loan characteristics, and the potential endogeneity of the arranger's selection). Given that in our sample loan tranches arranged by foreign arrangers have an average size of $\$ 199$ million, domestic arranger certification would have translated into an average reduction in the cost of debt of approximately $\$ 4.8$ million per tranche for these loans, thus demonstrating its economic value.

The rest of the paper proceeds as follows. Section 2 outlines some important institutional features of PF syndicated lending. Section 3 discusses the methodology. Section 4 reports our empirical results. Section 5 offers some concluding remarks.

\section{Institutional features of PF syndicated lending}

$\mathrm{PF}$ is the incorporation of a capital venture as a stand-alone investment with equity from sponsors and debt from lenders where the cash flows serve as the collateral for repayment (Finnerty, 2013). Cash flows are ring-fenced through a complex network of contracts to prevent any managerial discretion, thereby reducing conflict of interest and agency cost (Subramanian and Tung, 2016).

There are three important characteristics that distinguish PF from venture capital or corporate finance. First, a project company (also known as a special purpose vehicle $(\mathrm{SPV}))$ is created and given the legal mandate to design, construct and manage the project separately from its sponsors (Corielli et al., 2010). Second, the creation of the SPV gives rise to a set of contracts with third parties (often involving the sponsors as well) managed and coordinated by the board of directors of the SPV, appointed by the sponsors. Third, lenders provide the majority of capital (usually over 70\%) on a limited or nonrecourse basis typically through a syndicated structure led by a lead arranger (Yescombe, 2011; Gatti, 2013; Esty, 2004). The lead arranger conducts due diligence on the project company, its sponsors and counterparties, organizes the syndicate, and 
monitors the project company (Gatti et al., 2013). ${ }^{8}$ The selection of the lead arranger often takes place through a competitive tendering process with individual FIs or consortia of FIs tendering proposals to the project sponsors to act as lead arranger(s). ${ }^{9}$ When choosing the lead arranger, the sponsors look for a FI that can successfully syndicate the PF loan. This requires both distribution capability and the capability to certify the project's quality and risk (Gatti et al., 2013).

The syndication process involves three phases: pre-mandate, post-mandate and postsigning. The pre-mandate phase starts with the negotiation and drafting of the preliminary terms and conditions of the loan agreement between the project company and the MLA. The lead arranger must first conduct due diligence on the project company and the project itself to certify the project's true value and to ensure that relevant adverse inside information is revealed prior to loan syndication. This is particularly difficult since the project company has no prior operating history. Thus, the arranger has to access specialist engineering, legal, financial, logistical, market assessment, and risk assessment skills. The lead arranger must then develop a complex system of rules and financial covenants to monitor the project company's actions after the loan closing and throughout the life of the loan itself. This can be very challenging since many projects have extremely high upfront costs, but then generate large free cash flow streams after the project is completed (Esty and Megginson, 2003). The MLA then signs a preliminary loan agreement or "mandate" with the project company that specifies covenants, fees, and collateral. Next, in the post-mandate phase, the lead arranger is responsible for the organization of the syndicate. The MLA produces an information memorandum on the project company and sends it to potential participant lenders. Lenders with previous and existing relationships with the sponsors as well as those within the geographic reach of the project country are more likely to be invited to form the syndicate. A roadshow is often organized where potential participants are offered the opportunity to question the project company on any aspects of the project. The lead arranger must be able to attract a sufficient number and diversity of participating lenders to fund the PF loan at a price that is both low enough to ensure project solvency and high enough to adequately compensate the lenders for the risks they are taking by extending credit (Gatti et al., 2013). The lead arranger must also design an optimal loan syndicate (Lee and Mullineaux, 2004; Focarelli et al., 2008; Sufi, 2007) that can both deter strategic defaults (Esty and Megginson, 2003) and allow for efficient renegotiation in case of liquidity defaults. Once the participant lenders in the syndicate agree to fund part of the loan, the loan agreement is signed by all parties. Each participant is responsible for a share of the loan and the terms of the loan are identical for all syndicate members. The lead arranger, however, often holds a higher share of the loan than any of the other participants. In addition to interest and commitment fee income, the lead arranger receives a fee for arranging and managing the loan that is paid up-front by the project company and can be shared by the lead arranger and other syndicate members. In the post-signing phase, the lead arranger can also act as the agent bank for

\footnotetext{
${ }^{8}$ Lead arrangers can be commercial or investment banks but also insurance companies, pension funds, private equity funds, and sovereign wealth funds. Multilateral financing agencies such as development banks and export credit agencies (ECAs) can also act as lead arrangers, providing guarantees against political and country risks (Gatti, 2013; Hainz and Kleimeier, 2012).

${ }^{9}$ François and Missonier-Piera (2007) suggest that multiple lead arrangers in loan syndicates are the results of competitive advantages in various duties. They show that specialization helps split the costs of managing the syndicate.
} 
the bank syndicate as a whole. ${ }^{10}$ The agent monitors the project company, governs the terms of the loan, administers the drawdown of funds, calculates interest payments, and enforces financial covenants.

Arranger certification in PF differs from arranger certification in corporate finance. This is because while arrangers will naturally consider the balance sheets of the sponsors when structuring a corporate finance loan, this is irrelevant for PF lending due to the limited or nonrecourse nature of the loan agreement. In spite of this, Kleimeier and Megginson (2000) find that PF loans have lower spreads than many other types of syndicated loans, suggesting that the unique institutional and contractual features of PF and the underlying risk management process actually reduce default risk. Blanc-Brude and Strange (2007) show that public-private partnerships (PPP) lenders only price major risks, namely those driving the probability of default of the project, while managing other risks at the project level through contract and project design. Corielli et al. (2010) find that the use of nonfinancial contracts reduces loan spreads and increases debt-to-equity ratios through a reduction in agency cost and cash flow volatility. Sorge and Gadanecz (2008) find evidence of a positive non-linear hump-shaped term structure of PF loan spreads that is attributed to specific characteristics of PF deals including the sequential resolution of risks, and the availability of political risk guarantees.

\section{Methodology}

\subsection{Data}

We obtain our data on PF syndicated loans using data from Dealogic's ProjectWare database. ProjectWare contains comprehensive information on PF transactions including the loan contract characteristics, project company, sponsors and lenders. Importantly, ProjectWare lists all the FIs involved in a given PF transaction. Each PF deal typically involves several loan tranches. These loan tranches are the units of observation in our analysis. ${ }^{11}$ This introduces dependence between our observations, that is, all the loan tranches of a same deal are not independent of each other. Hence, we use robust standard errors clustered at the deal level.

We extract data from ProjectWare on more than 14,000 PF deals signed between 1998 and 2011. However, a main drawback with the ProjectWare database is the unavailability of data on loan spreads and fees for the majority of these deals. Thus, we are only able to retrieve a sample of approximately 5,000 loan tranches where loan spread information is available. We then filter out loan tranches that were not signed in emerging markets. To select countries that qualify as emerging markets we use the following four country list sources: the IMF's World Economic Outlook, the FTSE Annual Country Classification Review, the S\&P Dow Jones Country Classification Consultation Results, and the Russell Construction Methodology. This reduces our sample to approximately 2,000 loan tranches. To obtain a sample of syndicated loan tranches we filter out bilateral agreement and club financing loan tranches. Our final sample comprises 1,270 syndicated loan tranches (921 PF loan deals) arranged across 53 emerging markets between 1998 and 2011 and worth over $\$ 300$ billion.

\footnotetext{
${ }^{10}$ The agent bank is not necessarily the lead arranger bank.

${ }^{11} \mathrm{It}$ is a common feature in PF to structure a deal (e.g. bridge facility, revolving credit and term loans) with more than one loan tranche. The loan tranches may differ in maturity and spread. However, since these tranches fund the same deal they all reflect the deal's underlying characteristics.
} 
We create a dummy variable that equals one when a domestic FI acts as a mandated lead arranger in the loan syndicate and 0 otherwise. To contruct this dummy variable we track for each loan tranche the global ultimate ownership of each FI listed as a lead arranger using information on global ultimate owners (GUOs) contained in the Bankscope database (Bureau van Dijk). We also identify any change in the lead arranger's GUO over the sample period using information on mergers and acquisitions contained in the Zephyr database (Bureau van Dijk). Where this is the case, we classify the lead arranger as domestic or foreign based on its GUO at the time the deal was signed. ${ }^{12}$

\subsection{Description of the variables}

Table 1 provides a description of all the variables used in the analysis. Loan spread is the loan tranche spread over market base rates such as Libor, Euribor and US T-Bill. This is in line with Corielli et al. (2010), Blanc-Brude and Strange (2007), and Gatti et al. (2013). The loan spreads show some variation in their term structure. While most of the loan tranches have spreads charged as a single rate above a market base rate, some tranches are priced in tiers which correspond to various phases of the project such as construction and operational phases. To obtain a single rate for the tranche we calculate an average rate weighted by the number of years assigned to each tier of loan spread (see Corielli et al., 2010).

Size, maturity, guarantees (where the loan tranche has explicit political risk guarantees), refinance (where the loan tranche is to finance an on-going project), and currency (loan tranches in a currency which is different from the currency of the project country) are included to control for loan characteristics. We also control for the loan tranche type (i.e, secured, short-term, credit facility, term loan, EXIM), the project industry [and geographic location], and the project country's sovereign credit risk. The latter variable is constructed using credit risk scores compiled by the Institutional Investor magazine biannually (March and September) by means of interviews with economists from leading investment banks worldwide. The survey responses are used to derive a ranking that ranges from 1-100, with a higher score representing a better sovereign credit risk outlook. This measure is often preferred to other sovereign credit risk measures because of its periodic and forward looking nature as compared to measures released by rating agencies such as Standard \& Poor's, Moody or Fitch. Finally, for the purpose of model identification we consider the project country's ratio of domestic arrangers to total arrangers and the project country's level of financial development (measured by private credit to GDP). ${ }^{13}$ Data on private credit to GDP is obtained from the World Bank Financial Development and Structure Database originally developed by Beck et al. (2000).

\subsection{Model and estimation procedure}

Domestic lead arrangers may be able to select projects of differing quality compared to those selected by foreign lead arrangers. The effect is that the lead arranger's distribution across loan tranches may be non-random and systematically different within the population. If this is true, the effect of certification by domestic arrangers on spreads

\footnotetext{
${ }^{12}$ Where there are multiple lead arrangers for a given loan tranche, we categorize the loan tranche as arranged by a foreign arranger if all the lead arrangers without exception are foreign. Conversely, we categorize the loan tranche as arranged by a domestic arranger if at least one of the lead arrangers is domestic.

${ }^{13}$ Private credit to GDP is measured as the ratio of financial claims on the private sector by deposit money banks and other financial institutions divided by GDP in constant US\$.
} 
may not only measure domestic arranger certification, but may also indicate the ex ante characteristics of the projects selected by domestic arrangers. Thus, we treat the lead arranger's selection as potentially endogenous to the loan spread. Endogeneity of the arranger's selection may originate from several sources. First, domestic FIs' relatively superior knowledge of the borrower's country and of local market conditions (Berger et al., 2001; Mian, 2006) suggests domestic arrangers may have a comparative advantage in dealing with project companies that require more due diligence and monitoring. Second, domestic arrangers can help mitigate political risks associated with the project. Domestic FIs often have stronger political connections with the government of the borrower's country, making it difficult for the latter to take actions that jeopardize the viability of a PF investment, especially when the FI is state-owned (Esty, 2004). Third, domestic FIs may find it relatively more difficult than foreign FIs to fund large-scale investment ventures on a continuous basis due to greater liquidity constraints.

The potential endogeneity of the lead arranger's selection means that an ordinary least squares (OLS) estimate of the effect of certification by domestic arrangers on the loan spread may be biased. Our econometric approach takes this into account. We use the switching regression model with endogenous switching developed by Maddala (1986a,b). The basic model is composed of (i) a selection equation that determines which of the two "regimes" (loan tranches involving at least one domestic lead arranger or loan tranches involving only foreign lead arrangers) the loan tranche belongs to and (ii) two loan spread equations for loan tranches arranged by domestic arrangers and loan tranches arranged by foreign arrangers, respectively. The lead arranger's selection equation is specified as

$$
I_{i}=\alpha Z_{i}+\mu_{i}
$$

where $I_{i}$ is a binary variable, which equals 1 if for loan tranche $i$ a domestic FI is a mandated lead arranger, 0 otherwise. This can be summarized as

$$
\begin{aligned}
& I_{i}=1 \text { if } \alpha Z_{i}+\mu_{i}>0 \\
& I_{i}=0 \text { if } \alpha Z_{i}+\mu_{i} \leq 0
\end{aligned}
$$

The loan spread equations are specified as

$$
\begin{aligned}
& y_{1 i}=\beta_{1} X_{1 i}+\epsilon_{1 i} \\
& y_{2 i}=\beta_{2} X_{2 i}+\epsilon_{2 i}
\end{aligned}
$$

where $y_{1 i}\left(y_{2 i}\right)$ is the loan spread for loan tranche $i$ if it is arranged by one or more domestic arrangers (by foreign arrangers only). $Z_{i}, X_{1 i}$ and $X_{2 i}$ are sets of overlapping explanatory variables affecting both the arranger's selection and the loan tranche spread, with $\alpha, \beta_{1}$ and $\beta_{2}$ the respective coefficients. In our study, these explanatory variables are the loan tranche characteristics and the project country sovereign credit risk score as well as project industry dummies. We also include the project country's ratio of domestic arrangers to total arrangers and the project country's level of financial development (measured by private credit to GDP) in the selection equation for the purpose of model identification. In other words, we assume that these two variables only affect the loan tranche spread through their influence on the domestic arrangers' decision to certify. The ratio of domestic arrangers to total arrangers captures the pool of domestic financial intermediaries available to arrange a loan tranche in the project country. When this ratio is 
high domestic financial intermediaries supply a larger fraction of funds in PF loans. The level of financial development captures variation in financing capabilities. Together, the two variables capture variation in capital costs, which are likely to vary over time as conditions in the project countries' savings and investment markets change. While these two variables have been used to instrument arranger participation in previous studies (see, for instance, Nini, 2004), we nonetheless formally examine the validity of our exclusion restrictions in the robustness checks section below.

$\mu_{i}, \epsilon_{1 i}$ and $\epsilon_{2 i}$ are the error terms and assumed to have trivariate normal distribution with mean vector zero and covariance matrix shown below.

$$
\operatorname{cov}\left(\mu_{i}, \epsilon_{1 i}, \epsilon_{2 i}\right)=\left(\begin{array}{ccc}
\sigma_{\mu}^{2} & \sigma_{1 \mu} & \sigma_{2 \mu} \\
\sigma_{1 \mu} & \sigma_{1}^{2} & \sigma_{12} \\
\sigma_{2 \mu} & \sigma_{12} & \sigma_{2}^{2}
\end{array}\right)
$$

where $\sigma_{\mu}^{2}$ is the variance of the error term in the selection equation (which can be assumed to be equal to 1 since $\alpha$ is estimable up to a scalar factor). $\sigma_{1}^{2}$ and $\sigma_{2}^{2}$ are the variances of the error terms of the loan spread equations (2) and (3). $\sigma_{1 \mu}$ is the covariance of $\mu_{i}$ and $\epsilon_{1 i} . \sigma_{2 \mu}$ is the covariance of $\mu_{i}$ and $\epsilon_{2 i} . \sigma_{12}$ is the covariance between $\epsilon_{1 i}$ and $\epsilon_{2 i}$ and is not defined, as $y_{1 i}$ and $y_{2 i}$ are never observed simultaneously (Lokshin and Sajaia, 2004).

The model controls for the potential endogeneity of the arranger's selection using the error terms of the selection and outcome (loan spread) equations. In other words, unobserved characteristics that influence the arranger's selection may also influence the loan spread equations. Endogeneity of the arranger's selection implies that the expectations of the error terms for equations (2) and (3) conditional on the sample selection criterion have non-zero values. This is specified below as

$$
\begin{aligned}
& E\left(\epsilon_{1 i} / X_{i}, I_{i}=1\right)=\sigma_{1 \mu} \frac{F\left(\alpha Z_{i}\right)}{f\left(\alpha Z_{i}\right)} \neq 0 \\
& E\left(\epsilon_{2 i} / X_{i}, I_{i}=0\right)=-\sigma_{2 \mu} \frac{F\left(\alpha Z_{i}\right)}{1-f\left(\alpha Z_{i}\right)} \neq 0
\end{aligned}
$$

where $F$ is a cumulative normal distribution function and $f$ is a normal density distribution function.

The model is estimated using the maximum likelihood (ML) algorithm developed by Lokshin and Sajaia (2004) to fit the endogenous switching regression model. The log likelihood function is written as

$$
\begin{gathered}
\operatorname{LnL}=\sum\left(I _ { i } \left[\operatorname{Ln}\left\{\left(F\left(\phi_{1 i}\right)\right\}+\operatorname{Ln}\left\{f\left(\frac{\epsilon_{1 i}}{\sigma_{1}} / \sigma_{1}\right\}\right]+\left(1-I_{i}\right)\left[\operatorname{Ln}\left\{1-F\left(\phi_{2 i}\right)\right\}+\operatorname{Ln}\left\{f\left(\frac{\epsilon_{2 i}}{\sigma_{2}} / \sigma_{2}\right)\right\}\right]\right)\right.\right. \\
\phi_{j i}=\frac{\left(\alpha Z_{i}+\rho_{j} \epsilon_{j} / \sigma_{j}\right)}{\sqrt{1-\rho_{j}^{2}}}, j=1,2
\end{gathered}
$$

where $\rho_{1}=\sigma_{1 u}^{2} / \sigma_{u} \sigma_{1}$ is the correlation coefficient between $\epsilon_{1 i}$ and $\mu_{i}$ and $\rho_{2}=\sigma_{2 u}^{2} / \sigma_{u} \sigma_{2}$ is the correlation coefficient between $\epsilon_{2 i}$ and $\epsilon_{\mu}$. When the estimates of $\rho_{1}$ and $\rho_{2}$ are statistically different from zero the null hypothesis of no sample selection bias in the arranger's selection cannot be rejected. 


\subsection{Measuring the impact of domestic arranger certification}

As discussed earlier, the potential endogeneity of the arranger's selection means that loan tranches arranged by domestic arrangers in our sample may have systematically different characteristics from those arranged by foreign arrangers. Similarly, the error terms in the loan spread equations may be expected to be different for loan tranches arranged by domestic arrangers and loans tranches arranged by foreign arrangers. Therefore, we cannot measure the effect of certification by domestic arrangers simply by comparing the two conditional loan spreads obtained from estimating equations (2) and (3), as this would not take into account the potential sample selection bias in the arranger's selection. We compute instead the conditional and counterfactual loan spreads for loans arranged by foreign arrangers. The conditional loan spread is the loan spread for loan tranches arranged by foreign arrangers given that the loan tranches were actually arranged by foreign arrangers. In other words, this is the loan spread for loan tranches arranged by foreign arrangers after controlling for the potential sample selection bias in the arranger's selection. This is shown below in equation (8)

$$
E\left(y_{2 i} / I_{i}=0, X_{2 i}\right)=\beta_{2} X_{2 i}-\sigma_{2} \rho_{2} f\left(\alpha Z_{i}\right) /\left\{\left(1-F\left(\alpha Z_{i}\right)\right\}\right.
$$

The counterfactual loan spread is the loan spread that would have been observed for loan tranches arranged by foreign arrangers if these loan tranches involved one or more domestic arrangers instead of only involving foreign arrangers. This is shown below in equation (9)

$$
E\left(y_{1 i} / I_{i}=0, X_{1 i}\right)=\beta_{1} X_{1 i}-\sigma_{1} \rho_{1} f\left(\alpha Z_{i}\right) /\left\{\left(1-F\left(\alpha Z_{i}\right)\right\}\right.
$$

Based on the above, certification by domestic arrangers is valuable when the difference between the counterfactual loan spread (9) and conditional loan spread (8) is negative and statistically significant. Negative values indicate that certification by domestic arrangers would have resulted in lower loan spreads. ${ }^{14}$

\section{Empirical results}

\subsection{Comparison of loan tranches by type of arrangers}

Table 2 provides a univariate comparison of loan tranches by type of arrangers. The total size of loan tranches included in our sample is approximately $\$ 306$ billion. Loan tranches arranged by domestic arrangers are worth approximately $\$ 158$ billion, while those arranged by foreign arrangers are worth approximately $\$ 148$ billion ( $\$ 10$ billion less). Interestingly, there are more loan tranches arranged by foreign arrangers (744) than by domestic arrangers (526) despite the fact that the total size of loan tranches arranged by domestic arrangers is larger. This result indicates that foreign arrangers are likely to use a relatively more diffused tranche structure to arrange loans.

The mean loan spread for the whole sample is 216 bps with a standard deviation of 185.9 bps. Loan tranches arranged by domestic arrangers exhibit more variation (standard deviation of $232.7 \mathrm{bps}$ ) compared to those arranged by foreign arrangers (standard

\footnotetext{
${ }^{14}$ An alternative way of measuring the impact of domestic arranger certification is to compute the conditional and counterfactual loan spreads for loans arranged by domestic arrangers. The counterfactual loan spread in this case is the loan spread for loan tranches arranged by one or more domestic arrangers had these loan tranches been arranged by foreign arrangers only. Thus, domestic arranger certification is valuable if the counterfactual loan spread is greater than the conditional loan spread.
} 
deviation of $144.1 \mathrm{bps}$ ). The mean loan tranche maturity is 122 months (12.2 years) for the whole sample with the longest tenor equal to 393 months (32.8 years). Similarly, loan tranches arranged by domestic arrangers have a mean tenor equal to 147.9 months (12.3 years) compared to 103.8 months (8.7 years) for loan tranches arranged by foreign arrangers. The mean loan tranche size for the whole sample is $\$ 241.2$ million with the highest tranche size worth as much as $\$ 6.8$ billion. The mean size for loan tranches arranged by domestic arrangers is $\$ 301$ million compared to $\$ 199$ million for loan tranches arranged by foreign arrangers.

The mean sovereign credit risk score for loan tranches arranged by domestic arrangers is 65.8 , while it is 52.1 for those arranged by foreign arrangers. Thus, the loan tranches involving domestic arrangers in our sample tend to be in countries perceived to have lower sovereign risk. The mean ratio of private credit to GDP (our measure of financial development) is equal to $61 \%$ for the whole sample with the highest value equal to $159.6 \%$. The mean ratio of private credit to GDP is equal to $85.2 \%$ for loan tranches arranged by domestic arrangers compared to a mean ratio of $43.6 \%$ for loan tranches arranged by foreign arrangers. Hence, loan tranches involving domestic arrangers tend to be in countries that are relatively more financially developed.

\subsection{Distribution of loan tranches}

Table 3 shows the distribution of loan tranches by projects based on project industry, project region and project country income level. Oil and gas, power and utility, transportation, and telecommunication projects account for both the highest number and largest size of loan tranches in the sample. These projects account for approximately $74 \%$ of the total size of the loan tranches, which suggests that most of the funded projects in our sample are either energy or infrastructure related. Projects located in South-East Asia, the Middle East and Latin America account together for $69 \%$ of the total size of all the loan tranches in the sample. This is followed by projects in Eastern Europe accounting for $15 \%$ of the total size. Projects in the Indian subcontinent (India and Pakistan), Western Europe and Sub Saharan Africa together account for $16 \%$ of the total size. There appears to be a polarization of projects in high-income emerging economies, accounting for $50 \%$ of the total size of all the loan tranches. ${ }^{15}$ This is followed by upper-middle- and lower-middle-income countries, which account for $32 \%$ and $17 \%$, respectively. Low-income countries only account for $1 \%$ of the total size.

Table 4 shows the distribution of loan tranches by type of arrangers. Infrastructure projects like transportation, and water and sewage tend to involve relatively more domestic arrangers. Extractive projects such as mining, oil and gas, power and utility, as well as telecommunication projects tend to involve relatively more foreign arrangers. This could be because infrastructure projects receive more active government support, especially in countries such as Brazil and India (Ansar, 2012). Loan tranches arranged by domestic arrangers are also typically larger in size than those arranged by foreign arrangers. In terms of geographic location, more loan tranches are arranged by domestic arrangers in the Indian subcontinent and South-East Asia regions. The Sub-Saharan Africa, Western Europe, and Eastern Europe regions, in constrast, have more loan tranches arranged by foreign arrangers. The Middle East and South East Asia regions recorded the largest sizes for loan tranches arranged by domestic arrangers ( $\$ 63$ billion and $\$ 44$

\footnotetext{
${ }^{15}$ Countries are classified as high-income, upper-middle income, lower-middle income, and low income based on the World Bank's classification of countries by income.
} 
billion, respectively). Latin America and Eastern Europe recorded the largest sizes for loan tranches arranged by foreign arrangers ( $\$ 47$ billion and $\$ 34$ billion, respectively). The sample contains 293 loan tranches arranged by domestic arrangers in high-income emerging economies with a total size of $\$ 64$ billion. In lower middle-income countries there are only 82 loan tranches arranged by domestic arrangers with a total size of $\$ 25$ billion. In low-income countries, however, not a single loan tranche involved any domestic arrangers.

\subsection{Determinants of domestic arranger selection}

Table 5 reports the determinants of the domestic arranger's selection based on the selection equation of the endogenous switching regression model. The results show that domestic arrangers are more likely to arrange large and short term loan tranches and less likely to arrange loan tranches that are EXIM facilities. The coefficient on the tranche amount variable is positive and statistically significant at the $1 \%$ level across all four regressions. The coefficient of the short-term loan tranch dummy variable is positive and statistically significant at the $10 \%$ level once we control for the loan tranche type and the project's industry (Reg. 4). The finding that domestic arrangers appear to have a preference for loan deals with shorter maturity suggests that domestic banks may want to minimise long-term exposure to PF deals so as not to impact adversely on their other lending activities. The finding that EXIM loans are relatively less likely to be arranged by domestic arrangers as indicated by the negative and statistically significant coefficient on the EXIM loan tranche dummy variable in Reg. 3 and Reg. 4 supports our main hypothesis. Domestic banks may be better able to cultivate connections with the host government (see Mian, 2006), which can help mitigate political risks in PF. Since EXIM loans are guaranteed by sovereign institutions from developed countries, the economic value of domestic arranger certification may be much less significant for this particular type of loans.

Turning to the variables used for the purpose of model identification, namely the project country's ratio of domestic arrangers to total arrangers and the project country's level of financial development, the coefficients on these two variables are statistically significant across all four regressions. The positive and statistically significant coefficient on the former suggests that a larger pool of domestic banks available to arrange PF deals at the country level increases the proability that a domestic bank will act as lead arranger in a given deal. The negative and statistically significant coefficient on the latter once we control for the loan tranche type and the project's industry suggests a negative relationship between domestic arranger certification and financial development. This finding is somewhat intuitive. Financial development tends to be associated with openness to foreign investors, which include foreign financial intermediaries. Thus, the probability that a domestic bank acts as lead arranger in a PF deal reduces as the pool of banks available to certify PF deals in the country gets larger through the inclusion of foreign intermediaries. Furthermore, financial development also tends to be associated with greater transparency. If our our main hypothesis is true, greater transparency may reduce asymmetric information at the lead arranger level, thus reducing the economic value of domestic arranger certification.

\subsection{Loan spread regression results}

Tables 6 and 7 report the results of the loan spread regressions for loans arrranged by domestic arrangers and foreign arrangers, respectively. As Table 6 shows, sovereign 
credit risk score is negatively associated with loan spread for loans arranged by domestic arrangers. As expected, projects in higher ranked countries receive lower spreads. There is also a negative association between currency and loan spread. This result is fairly intuitive. Consider tranches denominated in US Dollars (USD), the USD equivalent credit exposure on the SPV fluctuates with currency movements, which impacts on the credit premium. As long as the loan is denominated in USD, the project company's exposure at default remains constant throughout the life of the loan. However, consider now the same loan is provided in Ghanaian Cedi (GHS). In this case, the exposure at default in USD depends on the exchange rate at the time of default. Last, the tranche size variable indicates that larger loans receive slightly lower spreads. Loan size reflects both the nature of the underlying project and its credit risk. Larger loans are typically granted to less risky project companies. When the SPV is based in a developing country and imports plants and equipment necessary to construct and operate the project, export credit agencies (ECAs) can provide various forms of financing (direct lending, indirect lending, and interest rate equalization) made available to them by their governments to encourage exports of goods and services or offer political and business risk coverage. The involvment of ECAs is captured in Reg. 3 and Reg. 4 by the EXIM loan tranches dummy. The results show that EXIM loan tranches are associated with higher spreads for loans arranged by domestic arrangers. This could reflect a relatively lower coverage of the entire risk insured by ECAs offering their services to national banks in developing countries.

Turning now to the results reported in Table 7, sovereign credit risk score and tranche size are both associated with a decrease in loan spread for tranches arranged by foreign arrangers. Hence, the effect of these two variables on loan spread remains unchanged when compared to Table 6. While foreign capital is often less constrained than local bank capital, in practice foreign financial intermediaries place country and borrower limits on the exposure that their loan desks can take. These limits are allocated by product, often resulting in loan specific country and borrower limits (Nini, 2004). This is further supported by the negative and significant association between spread and both shortterm and EXIM tranche dummy variables for loans arranged by foreign arrangers. The negative and significant coefficient on the EXIM dummy variable is consistent with the findings of Sorge and Gadanecz (2008) and suggests that the political and/or business risk insurance or guarantees that ECAs provide (when combined with certification by foreign arrangers) is effective at reducing the financing cost. Moreover, the negative association between currency and loan spread is comparatively weaker and less robust for loan tranches arranged by foreign arrangers than for those arranged by domestic arrangers. This is to be expected given that over $60 \%$ of the loan tranches in the sample are denominated in US Dollars with approximately $75 \%$ of US Dollar-denominated loan tranches arranged by foreign arrangers, typically international banks with large US Dollar reserves.

Finally, we observe a positive (negative) association between refinance (credit facility) and loan spread. This association, however, is no longer significant once we control for the project's industry. Overall, the findings reported in Tables 6 and 7 are broadly consistent with those reported in a number of studies examining the determinants of PF loan spread including inter alia Kleimeier and Megginson (2000), Corielli et al. (2010) and Gatti et al. (2013). 


\subsection{Impact of domestic arranger certification on loan spread}

The empirical estimates obtained from estimating Reg. 4, which are reported in Tables 6 and 7, are used to construct conditional and counterfactual loan spreads for loan tranches arranged by foreign arrangers using equations (8) and (9). The conditional and counterfactual loan spreads are converted from their natural logarithm form to basis points using the exponential function in order to compute the impact of certification by domestic arrangers on loan spreads in basis points. ${ }^{16}$ The spread impact is computed as the difference between the two expected loan spreads (conditional and counterfactual).

Table 8 reports the mean impact of domestic arranger certification on loan spreads in basis points. The table also report median, $25^{\text {th }}$, and $75^{\text {th }}$ percentile impact in basis points. The results are all statistically significant at the $1 \%$ level. The table reports impact by project industry, region and the country's income level. The mean basis point impact is -24 bps with $75^{\text {th }}$ percentile impact of $-44 \mathrm{bps}$. In other words, the mean loan spread for loan tranches arranged by foreign arrangers would have been 24 bps lower if these tranches had involved one or more domestic arrangers. The impact is highest for mining projects with a mean impact of -99 bps and median impact of $-66 \mathrm{bps}$. The $75^{\text {th }}$ percentile impact is relatively higher $(-146 \mathrm{bps})$. This is followed by projects in water and sewage, oil and gas, and industry and commercial projects. The projects where the impact is lowest are power and utility, and petrochemical projects. Overall, we find that domestic arranger certification has a positive impact on loan spread across all project industries except transportation. While transport finance initiatives should be designed to increase accessibility, capacity and performance, many investment projects are politically instead of commercially driven. The involvement of domestic financial intermediaries in the certification of such projects may increase the risk of political interference, leading to a higher credit premium.

Turning to impact by geographic location, Sub-Saharan Africa is where the impact of certification by domestic arrangers is the largest with a mean impact on spread of -112 bps and a $75^{\text {th }}$ percentile impact of -126 bps. In Latin America, the Indian subcontinent, and Eastern Europe, the mean impact on spread is -99 bps, -71 bps and -40 bps, respectively. The impact is lowest $(-31 \mathrm{bps})$ in the Middle East. Overall, certification by domestic arrangers appears to have a statistically and economically significant pricing effect on loans everywhere except Western Europe, which in our sample only comprises two countries: Greece and Israel.

Finally, for projects located in high-income emerging economies, the mean impact of certification by domestic arrangers on spread is -26 bps with a median impact of -17 bps. For projects located in upper middle-income countries, the mean impact is marginally lower at -20 bps with a median impact of -22 bps. The largest impact of domestic arranger certificatin on loan spread is found for projects located in lower income countries (mean impact of $-84 \mathrm{bps}$ with a median value of $-82 \mathrm{bps}$ ). The percentile values show that the lowest impact is $-61 \mathrm{bps}$ and the highest impact is $-116 \mathrm{bps}$. This finding is intuitive since lower income countries are typically characterized by relatively greater information asymmetry and country risk. Domestic arrangers in this context appear to be better able to signal the project's true value to other participants in the syndicate and reassure them

\footnotetext{
${ }^{16}$ Since the endogenous switching regression model is estimated using a natural logarithm function, the empirical results and the conditional and counterfactual loan spreads are also in natural logarithm form. We convert these spreads in basis points by computing the exponent of the estimates obtained using the natural logarithm function.
} 
that the project company will behave diligently. ${ }^{17}$

\subsection{Robustness checks}

The robustness of our results depends on the identification of appropriate exclusion restrictions - i.e. instruments - in order to tackle the endogeneity problem that may arise from selection bias in the lead arranger's selection. Specifically, it is important to employ instruments that are truly exogenous, that is, do not correlate with the error term in the loan spread equation. Furthermore, it is also important to avoid the use of weak instruments in the sense that the instruments do not significantly correlate with the potentially endogenous variable (i.e. the lead arranger's selection). The use of invalid and weak instruments can lead to coefficient estimates that involve greater biases as compared to results employing naïve OLS estimates. Thus, to investigate the robustness of our results we formally examine the validity of our exclusion restrictions. We do so by re-estimating Reg. 4 using a two-stage-least-square (2sls) approach and test the validity and relevance of the two instruments under this approach. ${ }^{18}$ One must, however, be cautious with respect to employing a linear approximation to model the selection into a treatment. Therefore, the estimates obtained using this approach are not strictly comparable to those obtained using the endogenous switching regression model reported in the previous section. In the present context, our use of the 2sls approach is solely for the purpose of testing our exclusion restrictions and not for the purpose of getting unbiased estimates of the regression coefficients. It is worth mentioning, however, that the 2sls regression results we obtain are qualitatively similar to the results obtained using the endogenous switching regression model. ${ }^{19}$ Last, it is of course not possible to compute conditional and counterfactual loan spreads using the 2sls approach, which justifies the use of the the endogenous switching regression model in the first place.

Table 9 reports the results of our validity and relevance tests. A necessary condition for testing the validity of instruments is to have an overidentified model, that is, to have more instruments that endogenous regressors. Our model is overidentified with two instruments (the project country's ratio of domestic arrangers to total arrangers, and the project country's level of financial development measured by private credit to GDP), and one endogenous regressor (the domestic arranger dummy variable). Given that a PF loan is often structured using more than one loan tranche, error terms at the tranche level are unlikely to be homoscedastic and serially uncorrelated. We first report the Kleibergen-Pap rk LM statistic. The test is robust to heteroskedasticity, serial correlation, and clustering. The instruments satisfy the rank condition since the statistic rejects the null hypothesis that the equation is underidentified. Next, we turn to the Hansen $J$ statistic, which tests the joint hypothesis that the model is correctly specified and the orthogonal condition is satisfied, and is robust to heteroskedasticity in the errors. The exclusion restrictions are satisfied since the test of overidentifying restrictions does not reject the null hypothesis that the instruments are uncorrelated with the error term. Last, we test for weak instruments using the Kleibergen and Paap rk Wald F-statistic, which is also robust to heteroskedasticity, serial correlation, and clustering. The test

\footnotetext{
${ }^{17}$ We do not report any results for loan tranches in low-income countries since these tranches did not involve any domestic arrangers in our sample.

${ }^{18}$ The endogenous switching regression Stata command movestay does not allow the user to test for instrument validity and relevance. Thus, we run the 2sls Stata command ivreg2, which allows the user to perform these tests.

${ }^{19}$ The 2 sls regression results are available upon request.
} 
rejects the null hypothesis that the instruments are weak. ${ }^{20}$ For completeness we also report the Cragg-Donald F-statistic despite it being valid only under i.i.d. errors (Baum et al., 2007).

\section{Conclusion}

Project finance has become an increasingly popular vehicle for channelling capital into emerging markets. Thompson Reuters Deals Intelligence reported that the total value of global PF transactions was worth $\$ 229.6$ billion in 2017 . Approximately $\$ 80.6$ billion $(35 \%)$ of these deals were signed in emerging markets. This paper explores the pricing effect of certification by domestic lead arrangers in PF loan syndication for 53 emerging markets over the period 1998-2011. After controlling for the potential endogeneity of the arranger's selection, our findings indicate that domestic arranger certification reduces the loan spread by 24 basis points on average. This amounts in our sample to a reduction in the cost of debt of approximately $\$ 4.8$ million per loan tranche. We show that this impact is greater for loan tranches financing projects in (i) mining, water and sewage, and oil and gas; (ii) the Sub-Saharan Africa, Latin America, and Indian subcontinent regions; and (iii) lower-income countries. Overall, our findings demonstrate the economic value of certification by domestic arrangers.

$\mathrm{PF}$ loans are a promising empirical laboratory for studying the importance of due diligence and monitoring duties in syndicated lending due to their unique contractual features. Our results suggest that, in the presence of information asymmetry between project sponsors and participant lenders in the syndicate, certification by domestic arrangers offers a superior mechanism to minimize the search, information and monitoring costs associated with PF lending. Viewed more broadly, these results provide new insight into an important function of homegrown or domestic financial intermediaries in developing economies.

\section{Acknowledgments}

We would like to thank Stefano Gatti, Bill Megginson, Alistair Milne, Alper Kara, Mark Freeman, Claudia Girardone, Azzim Gulamhussen, John Kjorstad, Jesper Von Zweigbergk, Martin Blaiklock, and an anonymous reviewer for their helpful comments and suggestions. All errors are our own.

\footnotetext{
${ }^{20}$ The rule of thumb proposed by Stock and Yogo (2005) is that the F-statistic for (joint) significance of the instruments in the first-stage should exceed 10.
} 


\section{References}

Alchian, A.A., Demsetz, H., 1972. Production, information costs, and economic organization. American Economic Review 62, 777-795.

Ansar, A., 2012. Project Finance in Emerging Markets. The Principles of Project Finance. Farnham, UK: Gower Publishing.

Baum, C.F., Schaffer, M.E., Stillman, S., 2007. Enhanced routines for instrumental variables/GMM estimation and testing. Stata Journal 7, 465-506.

Beck, T., Levine, R., Loayza, N., 2000. Finance and the sources of growth. Journal of Financial Economics 58, 261-300.

Berger, A.N., Klapper, L.F., Udell, G.F., 2001. The ability of banks to lend to informationally opaque small businesses. Journal of Banking and Finance 25, 2127-2167.

Blanc-Brude, F., Strange, R., 2007. How banks price loans to public-private partnerships: Evidence from the European markets. Journal of Applied Corporate Finance 19, 94106.

Brealey, R., Leland, H.E., Pyle, D.H., 1977. Informational asymmetries, financial structure, and financial intermediation. Journal of Finance 32, 371-387.

Buch, C.M., 2003. Information or regulation: What drives the international activities of commercial banks? Journal of Money, Credit and Banking, 851-869.

Chaudhry, S.M., Kleimeier, S., 2015. Lead arranger reputation and the structure of loan syndicates. Journal of International Financial Markets, Institutions and Money 38, $116-126$.

Corielli, F., Gatti, S., Steffanoni, A., 2010. Risk shifting through nonfinancial contracts: effects on loan spreads and capital structure of project finance deals. Journal of Money, Credit and Banking 42, 1295-1320.

Dailami, M., Leipziger, D., 1998. Infrastructure project finance and capital flows: A new perspective. World Development 26, 1283-1298.

Degryse, H., Ongena, S., 2005. Distance, lending relationships, and competition. Journal of Finance 60, 231-266.

Della Croce, R., Gatti, S., 2014. Financing infrastructure-international trends. Financial Market Trends 2014, 123-138.

Dennis, S.A., Mullineaux, D.J., 2000. Syndicated loans. Journal of Financial Intermediation 9, 404-426.

Diamond, D.W., 1984. Financial intermediation and delegated monitoring. Review of Economic Studies 51, 393-414.

Drucker, S., Puri, M., 2007. Banks in Capital Markets. Empirical Corporate Finance, ed. E. Eckbo, Handbooks in Finance, 189-232. Amsterdam: North-Holland Publishers. 
Esty, B., 2004. When do foreign banks finance domestic projects? New evidence on the importance of legal and financial systems. Available at SSRN: https://ssrn.com/abstract $=594526$.

Esty, B., 2014. An overview of project finance and infrastructure finance-2014 update. HBS Case .

Esty, B.C., Megginson, W.L., 2003. Creditor rights, enforcement, and debt ownership structure: Evidence from the global syndicated loan market. Journal of Financial and Quantitative Analysis 38, 37-60.

Finnerty, J.D., 2013. Project financing: Asset-based financial engineering. John Wiley and Sons.

Focarelli, D., Pozzolo, A.F., Casolaro, L., 2008. The pricing effect of certification on syndicated loans. Journal of Monetary Economics 55, 335-349.

François, P., Missonier-Piera, F., 2007. The agency structure of loan syndicates. Financial Review 42, 227-245.

Gande, A., Puri, M., Saunders, A., Walter, I., 1997. Bank underwriting of debt securities: Modern evidence. Review of Financial Studies 10, 1175-1202.

Gatti, S., 2013. Project finance in theory and practice: designing, structuring, and financing private and public projects. Academic Press.

Gatti, S., Kleimeier, S., Megginson, W., Steffanoni, A., 2013. Arranger certification in project finance. Financial Management 42, 1-40.

Giannetti, M., Ongena, S., 2012. Lending by example: Direct and indirect effects of foreign banks in emerging markets. Journal of International Economics 86, 167-180.

Hainz, C., Kleimeier, S., 2012. Political risk, project finance, and the participation of development banks in syndicated lending. Journal of Financial Intermediation 21, $287-314$.

Haselmann, R., Wachtel, P., 2011. Foreign banks in syndicated loan markets. Journal of Banking and Finance 35, 2679-2689.

Holmstrom, B., Tirole, J., 1997. Financial intermediation, loanable funds, and the real sector. Quarterly Journal of Economics 112, 663-691.

Ivashina, V., 2009. Asymmetric information effects on loan spreads. Journal of Financial Economics 92, 300-319.

Jensen, M.C., Meckling, W.H., 1976. Theory of the firm: Managerial behavior, agency costs and ownership structure. Journal of Financial Economics 3, 305-360.

Kanatas, G., Qi, J., 1998. Underwriting by commercial banks: Incentive conflicts, scope economies, and project quality. Journal of Money, Credit and Banking, 119-133.

Khanna, T., Palepu, K., 1999. Emerging market business groups, foreign investors, and corporate governance. No. W6955. National Bureau of Economic Research . 
Kleimeier, S., Chaudhry, S.M., 2015. Cultural differences and the structure of loan syndicates. Finance Research Letters 15, 115-124.

Kleimeier, S., Megginson, W.L., 2000. Are project finance loans different from other syndicated credits? Journal of Applied Corporate Finance 13, 75-87.

Knyazeva, A., Knyazeva, D., 2012. Does being your bank's neighbor matter? Journal of Banking and Finance 36, 1194-1209.

Kroszner, R.S., Rajan, R.G., 1997. Organization structure and credibility: Evidence from commercial bank securities activities before the Glass-Steagall Act. Journal of Monetary Economics 39, 475-516.

Lee, S.W., Mullineaux, D.J., 2004. Monitoring, financial distress, and the structure of commercial lending syndicates. Financial Management 33, 107-130.

Lokshin, M., Sajaia, Z., 2004. Maximum likelihood estimation of endogenous switching regression models. Stata Journal 4, 282-289.

Maddala, G., 1986a. Disequilibrium, self-selection, and switching models. Handbook of Econometrics. Elsevier North-Holland .

Maddala, G.S., 1986b. Limited-dependent and qualitative variables in econometrics. Cambridge University Press.

Mian, A., 2006. Distance constraints: The limits of foreign lending in poor economies. Journal of Finance 61, 1465-1505.

Narayanan, R.P., Rangan, K.P., Rangan, N.K., 2004. The role of syndicate structure in bank underwriting. Journal of Financial Economics 72, 555-580.

Nini, G., 2004. The value of financial intermediaries: Empirical evidence from syndicated loans to emerging market borrowers. FRB International Finance Discussion Paper .

Petersen, M.A., Rajan, R.G., 2002. Does distance still matter? The information revolution in small business lending. Journal of Finance 57, 2533-2570.

Puri, M., 1996. Commercial banks in investment banking conflict of interest or certification role? Journal of Financial Economics 40, 373-401.

Puri, M., 1999. Commercial banks as underwriters: implications for the going public process. Journal of Financial Economics 54, 133-163.

Sorge, M., Gadanecz, B., 2008. The term structure of credit spreads in project finance. International Journal of Finance \& Economics 13, 68-81.

Stock, J.H., Yogo, M., 2005. Testing for weak instruments in linear IV regression. Ch. 5 in Stock J. H., Andrews D. W. K. (Eds) Identification and Inference for Econometric Models: Essays in Honor of Thomas J. Rothenberg.

Subramanian, K.V., Tung, F., 2016. Law and project finance. Journal of Financial Intermediation 25, 154-177. 
Sufi, A., 2007. Information asymmetry and financing arrangements: Evidence from syndicated loans. Journal of Finance 62, 629-668.

Thomson-Reuters, 2017. Managing Underwriters - Full Year 2017. Global Project Finance Review. Available at http://dmi.thomsonreuters.com. .

Vu, T., Skully, M.T., 2008. Why do banks syndicate loans? New empirical evidence. Available at SSRN: https://ssrn.com/abstract $=1119743$.

Yescombe, E.R., 2011. Public-private partnerships: principles of policy and finance. Butterworth-Heinemann. 
Table 1: Description of the variables

\begin{tabular}{|c|c|}
\hline Variable & Description \\
\hline Loan Spread & Natural logarithm of the loan tranche spread over the base rate in basis points. \\
\hline Domestic Arranger & Dummy variable equal to 1 if a domestic financial intermediary is a MLA in the loan syndicate, 0 otherwise. \\
\hline Maturity & Natural logarithm of the loan tranche maturity measured in months. \\
\hline Size & Natural logarithm of the loan tranche size measured in million US Dollars. \\
\hline Guarantees & Dummy variable equal to 1 if the loan tranche has explicit political risk guarantees, 0 otherwise. \\
\hline Refinance & Dummy variable equal to 1 if the loan tranche refinances an ongoing project, 0 otherwise. \\
\hline Currency & Dummy variable equal to 1 if the loan tranche is in a currency other than the currency of the project country. \\
\hline II Credit Risk & Sovereign credit risk score. Ranges from 1 to 100. Source: Institutional Investor. \\
\hline Private Credit to GDP & Natural logarithm of private credit to GDP. Source: World Development Indicators. \\
\hline Ratio of domestic arrangers to total arrangers & Number of domestic arrangers divided by total number of arrangers at the country level. \\
\hline \multicolumn{2}{|l|}{ Loan Type } \\
\hline Secured & Dummy variable equal to 1 if the loan tranche is secured with a collateral, 0 otherwise. \\
\hline Short-Term & Dummy variable equal to 1 if the loan tranche is a short-term financing facility, 0 otherwise. \\
\hline Credit Facility & Dummy variable equal to 1 if the loan tranche is a credit facility, 0 otherwise. \\
\hline Term Loan & Dummy variable equal to 1 if the loan tranche is a term loan, 0 otherwise. \\
\hline EXIM & Dummy variable equal to 1 if the loan tranche is an EXIM facility, 0 otherwise. \\
\hline II Credit Risk*Year Dummies & Interaction of II Credit Risk variable and year dummies. \\
\hline \multicolumn{2}{|l|}{ Industry Dummies } \\
\hline Industry and Commercial & Dummy variable equal to 1 for an industrial and commercial project, 0 otherwise. \\
\hline Mining & Dummy variable equal to 1 for a mining project, 0 otherwise. \\
\hline Oil and Gas & Dummy variable equal to 1 for an oil and gas project, 0 otherwise. \\
\hline Petrochemical & Dummy variable equal to 1 for a petrochemical project, 0 otherwise. \\
\hline Telecom & Dummy variable equal to 1 for a telecommunication project, 0 otherwise. \\
\hline Transportation & Dummy variable equal to 1 for a transportation project, 0 otherwise. \\
\hline Water and Sewage & Dummy variable equal to 1 for a water and sewage project, 0 otherwise. \\
\hline
\end{tabular}

Source: ProjectWare by Dealogic (unless otherwise stated). 
Table 2: Univariate comparison of loan tranches by type of arrangers

\begin{tabular}{|c|c|c|c|c|c|c|c|}
\hline & Loan Tranches & Total & Percent & Mean & St. Dev. & Min & $\operatorname{Max}$ \\
\hline Spread (bps) & 1,270 & \multirow{6}{*}{$306,360.3$} & \multirow{6}{*}{$100 \%$} & 215.5 & 185.9 & 1 & 2,284 \\
\hline Maturity (months) & 1,252 & & & 122 & 75 & 0.96 & 393 \\
\hline Size (US\$ millions) & 1,270 & & & 241.2 & 403.6 & 0.32 & 6,787 \\
\hline Country credit score $(1-100)$ & 1,252 & & & 57.8 & 14.8 & 4.3 & 87.1 \\
\hline Country private credit to GDP $(\%)$ & 1,262 & & & 61 & 43.6 & 8.1 & 159.6 \\
\hline Ratio of domestic arrangers to total arrangers & 532 & & & 0.61 & 0.36 & 0.04 & 1 \\
\hline \multicolumn{8}{|l|}{ With domestic lead arrangers } \\
\hline Spread (bps) & 526 & \multirow{5}{*}{$158,301.6$} & \multirow{5}{*}{$52 \%$} & 214.9 & 232.7 & 10 & 2,284 \\
\hline Maturity (months) & 518 & & & 147.9 & 82.4 & 2.4 & 393 \\
\hline Size (US\$ millions) & 526 & & & 301 & 538 & 0.3 & $6,787.8$ \\
\hline Country credit score $(1-100)$ & 522 & & & 65.8 & 12.1 & 18.3 & 87.1 \\
\hline Country private credit to GDP (\%) & 525 & & & 85.2 & 48.3 & 9.4 & 159.6 \\
\hline \multicolumn{8}{|l|}{ With foreign lead arrangers only } \\
\hline Spread (bps) & 744 & \multirow{5}{*}{$148,058.7$} & \multirow{5}{*}{$48 \%$} & 215.9 & 144.1 & 1 & 1,150 \\
\hline Maturity (months) & 734 & & & 103.8 & 63.7 & 10 & 300 \\
\hline Size (US\$ millions) & 744 & & & 199 & 263.4 & 1.3 & $2,185.5$ \\
\hline Country credit score $(1-100)$ & 730 & & & 52.1 & 13.8 & 4.3 & 87.1 \\
\hline Country private credit to GDP (\%) & 737 & & & 43.6 & 29.5 & 8.1 & 159.6 \\
\hline
\end{tabular}


Table 3: Distribution of loan tranches by projects

\begin{tabular}{|c|c|c|c|c|c|c|c|}
\hline & Loan Tranches & Size (US\$ millions) & Percent & Mean & St. Dev. & Min & $\operatorname{Max}$ \\
\hline \multicolumn{8}{|l|}{ Industry } \\
\hline Industrial and Commercial & 64 & $17,511.4$ & $6 \%$ & 273.6 & 536 & 2.8 & 2,800 \\
\hline Mining & 48 & $10,447.5$ & $3 \%$ & 217.7 & 208 & 10 & 950 \\
\hline Oil and Gas & 205 & $79,764.3$ & $26 \%$ & 389.1 & 512.3 & 2.6 & 3,600 \\
\hline Petrochemical & 106 & $39,100.7$ & $13 \%$ & 368.9 & 363.9 & 15 & 2,000 \\
\hline Power \& Utility & 296 & $65,827.9$ & $21 \%$ & 222.4 & 307.9 & 1.3 & 2,672 \\
\hline Telecommunication & 175 & 30,757 & $10 \%$ & 175.8 & 287.1 & 3.9 & 2,451 \\
\hline Transportation & 195 & $50,546.8$ & $17 \%$ & 259.2 & 562.8 & 1.3 & 6,788 \\
\hline Water and Sewage & 60 & $2,515.5$ & $1 \%$ & 41.9 & 39.5 & 1.6 & 154 \\
\hline Other & 121 & $9,889.2$ & $3 \%$ & 81.2 & 147.5 & 0.3 & 1,314 \\
\hline Total & 1,270 & $306,360.3$ & $100 \%$ & & & & \\
\hline \multicolumn{8}{|l|}{ Region } \\
\hline Indian Subcontinent & 76 & $22,237.7$ & $7 \%$ & 292.6 & 442.9 & 10.3 & 2,672 \\
\hline Latin America & 299 & $59,717.5$ & $19 \%$ & 199.7 & 209.5 & 2.6 & $1,314.4$ \\
\hline Middle East & 218 & $92,201.5$ & $30 \%$ & 422.9 & 555.7 & 1.3 & 3,600 \\
\hline South-East Asia & 396 & $61,808.6$ & $20 \%$ & 156.1 & 403.3 & 0.3 & $6,787.8$ \\
\hline Sub-Saharan African & 52 & $11,298.2$ & $4 \%$ & 217.3 & 335.2 & 14.9 & 1,785 \\
\hline Western Europe & 70 & $13,742.9$ & $5 \%$ & 196.3 & 289.6 & 4.8 & $1,639.3$ \\
\hline Eastern Europe & 159 & 45,353 & $15 \%$ & 285.2 & 396.9 & 1.3 & $2,185.5$ \\
\hline Total & 1,270 & $306,360.3$ & $100 \%$ & & & & \\
\hline \multicolumn{8}{|l|}{ Country Income Level } \\
\hline High Income & 516 & $154,628.6$ & $50 \%$ & 299.7 & 458.8 & 0.3 & 3,600 \\
\hline Upper Middle Income & 509 & $98,796.4$ & $32 \%$ & 194.1 & 372.1 & 1.3 & $6,787.8$ \\
\hline Lower Middle Income & 239 & $50,761.6$ & $17 \%$ & 212.4 & 310.9 & 4.8 & 2,672 \\
\hline Lower Income & 6 & $2,173.7$ & $1 \%$ & 362.3 & 585.3 & 80 & 1,550 \\
\hline Total & 1,270 & $306,360.3$ & $100 \%$ & & & & \\
\hline
\end{tabular}

Sample period: $1998-2011$. 
Table 4: Distribution of loan tranches by type of arrangers

\begin{tabular}{|c|c|c|c|c|c|c|c|c|}
\hline & \multicolumn{2}{|c|}{ Loan Tranches } & \multicolumn{2}{|c|}{ Size (US\$ millions) } & \multicolumn{2}{|c|}{ Mean } & \multicolumn{2}{|c|}{ St. Dev. } \\
\hline & $\begin{array}{l}\text { Domestic } \\
\text { Arrangers }\end{array}$ & $\begin{array}{c}\text { Foreign } \\
\text { arrangers }\end{array}$ & $\begin{array}{l}\text { Domestic } \\
\text { arrangers }\end{array}$ & $\begin{array}{c}\text { Foreign } \\
\text { arrangers }\end{array}$ & $\begin{array}{l}\text { Domestic } \\
\text { arrangers }\end{array}$ & $\begin{array}{c}\text { Foreign } \\
\text { arrangers }\end{array}$ & $\begin{array}{l}\text { Domestic } \\
\text { arrangers }\end{array}$ & $\begin{array}{c}\text { Foreign } \\
\text { arrangers }\end{array}$ \\
\hline \multicolumn{9}{|l|}{ Industry } \\
\hline Industrial and Commercial & 35 & 29 & $14,200.9$ & $3,310.5$ & 405.7 & 114.2 & 680.6 & 189.2 \\
\hline Mining & 10 & 38 & $2,065.9$ & $8,381.6$ & 206.6 & 220.6 & 222.3 & 207.2 \\
\hline Oil and Gas & 46 & 159 & $26,830.5$ & $52,933.8$ & 583.3 & 332.9 & 819.4 & 365.3 \\
\hline Petrochemical & 55 & 51 & $23,598.7$ & $15,502.1$ & 429.1 & 304 & 356.2 & 363.8 \\
\hline Power and Utility & 98 & 198 & $31,292.4$ & $34,535.4$ & 319.3 & 174.4 & 429.3 & 210.4 \\
\hline Telecommunication & 37 & 138 & 10,711 & 20,046 & 289.5 & 145.3 & 482 & 198 \\
\hline Transportation & 134 & 61 & $43,231.5$ & $7,315.3$ & 322.6 & 119.9 & 663.7 & 137.4 \\
\hline Water and Sewage & 32 & 28 & $1,062.1$ & $1,453.4$ & 33.19 & 51.9 & 29.4 & 47.1 \\
\hline Other & 79 & 42 & $5,308.6$ & $4,580.6$ & 67.2 & 106.8 & 164 & 108.2 \\
\hline Total & 526 & 744 & $158,301.6$ & $148,058.7$ & & & & \\
\hline \multicolumn{9}{|l|}{ Region } \\
\hline Indian Subcontinent & 53 & 23 & $18,313.2$ & $3,924.5$ & 345.5 & 170.6 & 509.1 & 183.9 \\
\hline Latin America & 44 & 255 & $12,798.6$ & $46,918.9$ & 290.9 & 184 & 301.3 & 185.5 \\
\hline Middle East & 103 & 115 & $62,503.5$ & 29,698 & 606.8 & 258.2 & 708.8 & 283.5 \\
\hline South-East Asia & 259 & 137 & $43,606.2$ & $18,202.4$ & 168.4 & 132.9 & 484.9 & 160.1 \\
\hline Sub-Saharan African & 7 & 45 & $1,464.3$ & $9,833.9$ & 209.2 & 218.5 & 135 & 357.4 \\
\hline Western Europe & 20 & 50 & 8,672 & $5,070.9$ & 433.6 & 101.4 & 429.8 & 119.5 \\
\hline Eastern Europe & 40 & 119 & $10,943.8$ & $34,410.1$ & 273.6 & 289.2 & 333.6 & 417.3 \\
\hline Total & 526 & 744 & $158,301.6$ & $148,058.7$ & & & & \\
\hline \multicolumn{9}{|l|}{ Country Income Level } \\
\hline High Income & 293 & 223 & $90,970.3$ & $63,658.3$ & 310.5 & 285.5 & 521 & 361.9 \\
\hline Upper Middle Income & 151 & 358 & $42,684.2$ & $56,112.2$ & 282.7 & 156.7 & 621.9 & 173.3 \\
\hline Lower Middle Income & 82 & 157 & $24,647.1$ & $26,114.5$ & 300.6 & 217.7 & 425.1 & 217.7 \\
\hline Lower Income & 0 & 6 & 0 & $2,173.7$ & 0 & 362.3 & 0 & 585.3 \\
\hline Total & 526 & 744 & $158,301.6$ & $148,058.7$ & & & & \\
\hline
\end{tabular}

Sample period: $1998-2011$. 
Table 5: Determinants of domestic arranger selection

\begin{tabular}{|c|c|c|c|c|}
\hline & Reg. 1 & Reg. 2 & Reg. 3 & Reg. 4 \\
\hline Maturity & $\begin{array}{c}0.073 \\
(0.081)\end{array}$ & $\begin{array}{c}-0.036 \\
(0.079)\end{array}$ & $\begin{array}{c}0.027 \\
(0.085)\end{array}$ & $\begin{array}{c}0.009 \\
(0.086)\end{array}$ \\
\hline Size & $\begin{array}{c}0.203^{* * *} \\
(0.048)\end{array}$ & $\begin{array}{c}0.177^{* * *} \\
(0.044)\end{array}$ & $\begin{array}{c}0.180^{* * *} \\
(0.045)\end{array}$ & $\begin{array}{c}0.162^{* * *} \\
(0.046)\end{array}$ \\
\hline Guarantees & $\begin{array}{l}-0.489 \\
(0.348)\end{array}$ & $\begin{array}{l}-0.549 \\
(0.426)\end{array}$ & $\begin{array}{c}-0.606 \\
(0.435)\end{array}$ & $\begin{array}{l}-0.572 \\
(0.425)\end{array}$ \\
\hline Refinance & $\begin{array}{c}0.127 \\
(0.160)\end{array}$ & $\begin{array}{c}0.115 \\
(0.159)\end{array}$ & $\begin{array}{c}0.110 \\
(0.162)\end{array}$ & $\begin{array}{c}0.128 \\
(0.161)\end{array}$ \\
\hline Currency & $\begin{array}{l}-0.083 \\
(0.348)\end{array}$ & $\begin{array}{l}-0.181 \\
(0.272)\end{array}$ & $\begin{array}{c}-0.157 \\
(0.277)\end{array}$ & $\begin{array}{c}-0.132 \\
(0.294)\end{array}$ \\
\hline II Credit Risk & $\begin{array}{c}0.020^{* * *} \\
(0.006)\end{array}$ & $\begin{array}{c}0.013 \\
(0.009)\end{array}$ & $\begin{array}{c}0.012 \\
(0.009)\end{array}$ & $\begin{array}{c}0.012 \\
(0.009)\end{array}$ \\
\hline Private Credit to GDP & $\begin{array}{c}-0.007^{* *} \\
(0.003)\end{array}$ & $\begin{array}{c}-0.007^{* *} \\
(0.003)\end{array}$ & $\begin{array}{c}-0.007^{* *} \\
(0.003)\end{array}$ & $\begin{array}{c}-0.007^{* *} \\
(0.003)\end{array}$ \\
\hline Domestic arrangers to total arrangers & $\begin{array}{c}6.262^{* * *} \\
(0.984)\end{array}$ & $\begin{array}{c}6.294^{* * *} \\
(0.903)\end{array}$ & $\begin{array}{c}6.303^{* * *} \\
(0.904)\end{array}$ & $\begin{array}{c}6.249 * * * \\
(0.905)\end{array}$ \\
\hline Secured & & & $\begin{array}{l}-0.102 \\
(0.370)\end{array}$ & $\begin{array}{l}-0.108 \\
(0.363)\end{array}$ \\
\hline Short Term & & & $\begin{array}{c}0.491 \\
(0.303)\end{array}$ & $\begin{array}{l}0.532^{*} \\
(0.304)\end{array}$ \\
\hline Credit Facility & & & $\begin{array}{l}-0.002 \\
(0.444)\end{array}$ & $\begin{array}{c}0.024 \\
(0.444)\end{array}$ \\
\hline Term Loan & & & $\begin{array}{c}0.170 \\
(0.261)\end{array}$ & $\begin{array}{c}0.178 \\
(0.264)\end{array}$ \\
\hline EXIM & & & $\begin{array}{c}-1.261^{*} \\
(0.700)\end{array}$ & $\begin{array}{c}-1.240^{*} \\
(0.693)\end{array}$ \\
\hline Constant & $\begin{array}{c}-3.353^{* * *} \\
(0.527)\end{array}$ & $\begin{array}{c}-2.264^{* * *} \\
(0.568)\end{array}$ & $\begin{array}{c}-2.270 * * * \\
(0.644)\end{array}$ & $\begin{array}{c}-2.732^{* * *} \\
(0.784)\end{array}$ \\
\hline II Credit Risk*Year Dummies & No & Yes & Yes & Yes \\
\hline Industry Dummies & No & No & No & Yes \\
\hline No. of observations & 1,227 & 1,227 & 1,227 & 1,227 \\
\hline
\end{tabular}

Dependent variable: Domestic Arranger. Sample period: 1998-2011. Deal level clustered robust standard errors in parentheses. $*, * *, * * *$ indicate significance at the $10 \%, 5 \%$, and $1 \%$ levels, respectively. 
Table 6: Loan spread regression results for loans arranged by domestic arrangers

\begin{tabular}{|c|c|c|c|c|}
\hline & Reg. 1 & Reg. 2 & Reg. 3 & Reg. 4 \\
\hline Maturity & $\begin{array}{l}-0.064 \\
(0.049)\end{array}$ & $\begin{array}{l}-0.053 \\
(0.045)\end{array}$ & $\begin{array}{c}-0.109^{* *} \\
(0.049)\end{array}$ & $\begin{array}{c}-0.119^{* *} \\
(0.050)\end{array}$ \\
\hline Size & $\begin{array}{c}-0.047^{*} \\
(0.026)\end{array}$ & $\begin{array}{c}-0.057^{* * *} \\
(0.022)\end{array}$ & $\begin{array}{c}-0.060^{* * *} \\
(0.021)\end{array}$ & $\begin{array}{c}-0.069 * * * \\
(0.025)\end{array}$ \\
\hline Guarantees & $\begin{array}{c}-0.181 \\
(0.343)\end{array}$ & $\begin{array}{l}-0.119 \\
(0.354)\end{array}$ & $\begin{array}{l}-0.058 \\
(0.326)\end{array}$ & $\begin{array}{c}-0.029 \\
(0.286)\end{array}$ \\
\hline Refinance & $\begin{array}{c}0.062 \\
(0.123)\end{array}$ & $\begin{array}{c}0.039 \\
(0.117)\end{array}$ & $\begin{array}{c}0.032 \\
(0.115)\end{array}$ & $\begin{array}{l}-0.007 \\
(0.109)\end{array}$ \\
\hline Currency & $\begin{array}{c}-0.493^{* * *} \\
(0.114)\end{array}$ & $\begin{array}{c}-0.508^{* * *} \\
(0.102)\end{array}$ & $\begin{array}{c}-0.509^{* * *} \\
(0.100)\end{array}$ & $\begin{array}{c}-0.440 * * * \\
(0.106)\end{array}$ \\
\hline II Credit Risk & $\begin{array}{c}-0.011^{*} \\
(0.004)\end{array}$ & $\begin{array}{c}-0.029^{* * *} \\
(0.004)\end{array}$ & $\begin{array}{c}-0.029 * * * \\
(0.004)\end{array}$ & $\begin{array}{c}-0.028 * * * \\
(0.005)\end{array}$ \\
\hline Secured & & & $\begin{array}{c}-0.107 \\
(0.221)\end{array}$ & $\begin{array}{c}-0.53 \\
(0.227)\end{array}$ \\
\hline Short Term & & & $\begin{array}{c}0.008 \\
(0.185)\end{array}$ & $\begin{array}{l}-0.060 \\
(0.179)\end{array}$ \\
\hline Credit Facility & & & $\begin{array}{c}0.150 \\
(0.260)\end{array}$ & $\begin{array}{c}0.045 \\
(0.275)\end{array}$ \\
\hline Term Loan & & & $\begin{array}{c}0.278 \\
(0.175)\end{array}$ & $\begin{array}{c}0.250 \\
(0.178)\end{array}$ \\
\hline EXIM & & & $\begin{array}{c}1.372^{* * *} \\
(0.184)\end{array}$ & $\begin{array}{c}1.169^{* * *} \\
(0.220)\end{array}$ \\
\hline Constant & $\begin{array}{c}6.495^{* * *} \\
(0.390)\end{array}$ & $\begin{array}{c}6.880^{* * *} \\
(0.352)\end{array}$ & $\begin{array}{c}6.863^{* * *} \\
(0.421)\end{array}$ & $\begin{array}{c}6.846^{* * *} \\
(0.472)\end{array}$ \\
\hline II Credit Risk*Year Dummies & No & Yes & Yes & Yes \\
\hline Industry Dummies & No & No & No & Yes \\
\hline$\rho_{1}$ & $\begin{array}{c}0.153 \\
(0.130)\end{array}$ & $\begin{array}{c}0.223 \\
(0.139)\end{array}$ & $\begin{array}{c}0.241 \\
(0.133)\end{array}$ & $\begin{array}{c}0.253 \\
(0.153)\end{array}$ \\
\hline No. of observations & 1,227 & 1,227 & 1,227 & 1,227 \\
\hline
\end{tabular}

Dependent variable: Loan Spread. Sample period: 1998-2011. Deal level clustered robust standard errors in parentheses. *,**,*** indicate significance at the $10 \%, 5 \%$, and $1 \%$ levels, respectively. 
Table 7: Loan spread regression results for loans arranged by foreign arrangers

\begin{tabular}{|c|c|c|c|c|}
\hline & Reg. 1 & Reg. 2 & Reg. 3 & Reg. 4 \\
\hline Maturity & $\begin{array}{c}0.034 \\
(0.052)\end{array}$ & $\begin{array}{c}0.040 \\
(0.040)\end{array}$ & $\begin{array}{c}0.016 \\
(0.041)\end{array}$ & $\begin{array}{c}-0.001 \\
(0.042)\end{array}$ \\
\hline Size & $\begin{array}{c}-0.071^{* *} \\
(0.030)\end{array}$ & $\begin{array}{c}-0.083^{* * *} \\
(0.029)\end{array}$ & $\begin{array}{c}-0.086^{* * *} \\
(0.031)\end{array}$ & $\begin{array}{c}-0.079^{* *} \\
(0.033)\end{array}$ \\
\hline Guarantees & $\begin{array}{c}-0.080 \\
(0.100)\end{array}$ & $\begin{array}{c}-0.071 \\
(0.103)\end{array}$ & $\begin{array}{c}-0.053 \\
(0.103)\end{array}$ & $\begin{array}{l}-0.084 \\
(0.107)\end{array}$ \\
\hline Refinance & $\begin{array}{c}0.249^{* * *} \\
(0.093)\end{array}$ & $\begin{array}{c}0.204^{* *} \\
(0.087)\end{array}$ & $\begin{array}{c}0.172^{* *} \\
(0.087)\end{array}$ & $\begin{array}{c}0.113 \\
(0.086)\end{array}$ \\
\hline Currency & $\begin{array}{c}-0.258^{* *} \\
(0.130)\end{array}$ & $\begin{array}{c}-0.193^{*} \\
(0.114)\end{array}$ & $\begin{array}{c}-0.151 \\
(0.112)\end{array}$ & $\begin{array}{l}-0.157 \\
(0.153)\end{array}$ \\
\hline II Credit Risk & $\begin{array}{c}-0.001^{* * *} \\
(0.003)\end{array}$ & $\begin{array}{c}-0.025^{* * *} \\
(0.004)\end{array}$ & $\begin{array}{c}-0.025^{* * *} \\
(0.004)\end{array}$ & $\begin{array}{c}-0.026^{* * *} \\
(0.004)\end{array}$ \\
\hline Secured & & & $\begin{array}{c}-0.039 \\
(0.149)\end{array}$ & $\begin{array}{c}0.083 \\
(0.152)\end{array}$ \\
\hline Short Term & & & $\begin{array}{c}-0.488^{* * *} \\
(0.148)\end{array}$ & $\begin{array}{c}-0.490^{* * *} \\
(0.149)\end{array}$ \\
\hline Credit Facility & & & $\begin{array}{c}-0.285^{*} \\
(0.162)\end{array}$ & $\begin{array}{l}-0.228 \\
(0.164)\end{array}$ \\
\hline Term Loan & & & $\begin{array}{c}-0.139 \\
(0.121)\end{array}$ & $\begin{array}{l}-0.135 \\
(0.123)\end{array}$ \\
\hline EXIM & & & $\begin{array}{c}-1.404^{* * *} \\
(0.270)\end{array}$ & $\begin{array}{c}-1.465^{* * *} \\
(0.268)\end{array}$ \\
\hline Constant & $\begin{array}{c}6.081^{* * *} \\
(0.295)\end{array}$ & $\begin{array}{c}6.376^{* * *} \\
(0.300)\end{array}$ & $\begin{array}{c}6.640^{* * *} \\
(0.305)\end{array}$ & $\begin{array}{c}6.256^{* * *} \\
(0.305)\end{array}$ \\
\hline II Credit Risk*Year Dummies & No & Yes & Yes & Yes \\
\hline Industry Dummies & No & No & No & Yes \\
\hline$\rho_{2}$ & $\begin{array}{c}0.073 \\
(0.189)\end{array}$ & $\begin{array}{c}0.105 \\
(0.328)\end{array}$ & $\begin{array}{c}0.165 \\
(0.421)\end{array}$ & $\begin{array}{c}0.204 \\
(0.392)\end{array}$ \\
\hline No. of observations & 1,227 & 1,227 & 1,227 & 1,227 \\
\hline
\end{tabular}

Dependent variable: Loan Spread. Sample period: 1998-2011. Deal level clustered robust standard errors in parentheses. *,**,*** indicate significance at the $10 \%, 5 \%$, and $1 \%$ levels, respectively. 
Table 8: Impact of certification by domestic arrangers on loan spreads

\begin{tabular}{|c|c|c|c|c|}
\hline & \multicolumn{4}{|c|}{ Basis Point Impact } \\
\hline & Mean & $25^{\text {th }}$ percentile & Median & $75^{t h}$ percentile \\
\hline All loan tranches & -24 & -10 & -17 & -44 \\
\hline \multicolumn{5}{|l|}{ By Industry } \\
\hline Industry and Commercial & -55 & -12 & 1 & -76 \\
\hline Mining & -99 & -82 & -66 & -146 \\
\hline Oil and Gas & -62 & -31 & -74 & -77 \\
\hline Petrochemical & -30 & -24 & -23 & -34 \\
\hline Power and Utility & -29 & -25 & -45 & -66 \\
\hline Telecommunication & -50 & -41 & -51 & -52 \\
\hline Transportation & 7 & -1 & 17 & 21 \\
\hline Water and Sewage & -83 & -10 & -41 & -112 \\
\hline \multicolumn{5}{|l|}{ By Region } \\
\hline Eastern Europe & -40 & -38 & -45 & -54 \\
\hline Indian Subcontinent & -71 & -67 & -81 & -54 \\
\hline Latin America & -99 & -90 & -130 & -118 \\
\hline Middle East & -31 & -22 & -28 & -26 \\
\hline South East Asia & -8 & 10 & -8.2 & -13 \\
\hline Sub Saharan Africa & -112 & -55 & -144 & -126 \\
\hline Western Europe & 65 & 6 & 12 & 38 \\
\hline \multicolumn{5}{|l|}{ By Country Income Level } \\
\hline High Income & -26 & -12 & -17 & -20 \\
\hline Upper Middle Income & -20 & -19 & -22 & -49 \\
\hline Lower Middle Income & -84 & -61 & -82 & -116 \\
\hline
\end{tabular}

Sample period: $1998-2011$. All values are statistically significant at the $1 \%$ level. 
Table 9: Robustness tests results

Underidentification test

Kleibergen-Paap rk LM statistic

155.1

(0.000)

Overidentification test

Hansen J statistic

0.936

(0.333)

Weak instruments tests

Cragg-Donald Wald F-statistic

Kleibergen-Paap rk Wald F-statistic

$p$-values in parentheses. 